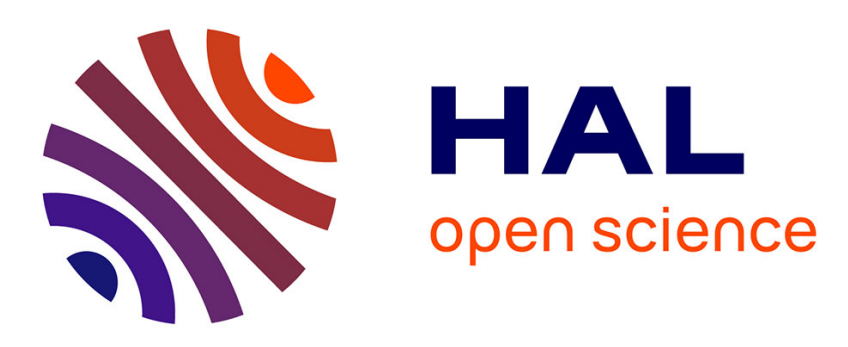

\title{
Influence of dietary soy isoflavones on the accessory sex organs of the Wistar rat
}

Thomas Stroheker, Nicolas J. Cabaton, Raymond Berges, Valérie Lamothe, Jean-Claude Lhuguenot, Marie-Christine Chagnon

\section{To cite this version:}

Thomas Stroheker, Nicolas J. Cabaton, Raymond Berges, Valérie Lamothe, Jean-Claude Lhuguenot, et al.. Influence of dietary soy isoflavones on the accessory sex organs of the Wistar rat. Food and Chemical Toxicology, 2003, 41 (8), pp.1175-83. 10.1016/S0278-6915(03)00108-X . hal-02681581

\section{HAL Id: hal-02681581 https://hal.inrae.fr/hal-02681581}

Submitted on 31 May 2020

HAL is a multi-disciplinary open access archive for the deposit and dissemination of scientific research documents, whether they are published or not. The documents may come from teaching and research institutions in France or abroad, or from public or private research centers.
L'archive ouverte pluridisciplinaire HAL, est destinée au dépôt et à la diffusion de documents scientifiques de niveau recherche, publiés ou non, émanant des établissements d'enseignement et de recherche français ou étrangers, des laboratoires publics ou privés. 


\title{
Influence of dietary soy isoflavones on the accessory sex organs of the Wistar rat
}

\author{
Thomas Stroheker ${ }^{\mathrm{a}}$, Nicolas Cabaton ${ }^{\mathrm{a}}$, Raymond Berges ${ }^{\mathrm{b}}$, Valérie Lamothe ${ }^{\mathrm{c}}$, \\ Jean-Claude Lhuguenot ${ }^{\mathrm{a}}$, Marie-Christine Chagnon ${ }^{\mathrm{a}, *}$ \\ ${ }^{a}$ UMR 0938 de Toxicologie Alimentaire, Ensbana, 1 esplanade Erasme, 21000 Dijon, France \\ b Animalerie Expérimentale Nutrition, 17 Rue Sully, 21000 Dijon, France \\ ${ }^{\mathrm{c}}$ Unité Micronutriments, Reproduction, Santé, Enita Bordeaux, 1 cours Général de Gaulle, 33175 Gradignan, France
}

Accepted 14 March 2003

\begin{abstract}
We evaluated the effects of three rodent diets differing in soybean meal content on the response of the seminal vesicles, prostate and bulbocavernosus/levator ani (BC/LA) muscle to androgens and anti-androgenic compounds in the Hershberger assay. The diets tested were (1) L5, a semi-synthetic phytoestrogen-free diet, (2) DO4, 8.5\% (w/w) vegetable protein and (3) DO3, 22.5\% (w/w) vegetable protein. We determined the effects of dietary soy isoflavones after ten days of exposure and in animals fed L5 and DO3 diets throughout their lifetime (including the period of treatment with androgenic or anti-androgenic compounds). After ten days of exposure, we observed no effect of diet on the accessory sex organs of male Wistar rats. In contrast, diet affected the androgenic response to testosterone propionate in seminal vesicles and prostate. Seminal vesicles were the most sensitive organs. Vinclozolin caused a dose-dependent decrease in the relative weights of seminal vesicles, prostate and $\mathrm{BC} / \mathrm{LA}$ regardless of diet. As vegetable proteins may contain high proportions of genistein and daidzein, two well-known oestrogenic endocrine disrupters that may alter the results of reproductive studies, we recommend the use of a standardised open-formula diet without soy isoflavones, such as L5, if the Hershberger assay is to be performed.
\end{abstract}

(C) 2003 Elsevier Science Ltd. All rights reserved.

Keywords: Hershberger assay; Rodent diet; Vinclozolin; Testosterone propionate

\section{Introduction}

The Hershberger assay was designed to monitor the androgenic and myotrophic activity of steroids by assessing the ability of these molecules to induce growth in the levator ani muscle, seminal vesicles, and prostate of weaned castrated rats (Hershberger et al., 1953). Since 1998, this assay has also been recommended for

Abbreviations: TP, testosterone propionate, VCZ, vinclozolin, BC/LA, bulbo cavernosus/levator ani muscle, PND, postnatal day, S.D., standard deviation, SEM, standard error of the mean, DHT, $5 \alpha-$ dihydrotestosterone.

* Corresponding author. Tel.: +33-3-80-39-66-37; fax: 33-3-80-3966-41.

E-mail address: mcchagn@u-bourgogne.fr (M.-C. Chagnon). the assessment of anti-androgenic activity in immature male rats (EDSTAC, 1998).

Natural compounds with oestrogenic properties (phytoestrogens) are present in many plants, including a number of food crops: soybean and derivative products, peas, alfalfa, beans (Verdeal and Ryan, 1979; Reinli and Block, 1996; Mazur, 1998). Some rodent diets contain soybean meal, a major source of daidzein and genistein, two well-known oestrogenic isoflavones (Bickoff et al., 1962; Kurzer and Xu, 1997; Welshons et al., 1990; Yamasaki et al., 2002). Daidzein and genistein may therefore be present in the natural ingredients of rodent diets at concentrations that could have marked effects on the in vivo endpoints of hormone action. This might affect the results of studies investigating the oestrogenic and reproductive activity of various compounds (Thigpen et al., 1999). 
A rodent diet containing large amounts of daidzein $(14 \mu \mathrm{g} / \mathrm{g})$ and genistein $(210 \mu \mathrm{g} / \mathrm{g})$ has been reported to induce a near-maximal uterotrophic response in control and ovariectomised, 30-day-old Sprague-Dawley rats. This diet also affected the response to administered oestradiol (Boettger-Tong et al., 1998). Odum et al. (2001) demonstrated uterotrophic activity for a diet rich in phytoestrogens (Purina 5001, $290 \mu \mathrm{g} / \mathrm{g}$ ), which was compared with a standard RM1 diet. These findings stress the importance of defining the type and source of diets used in rodent toxicity studies. Oestrogenic compounds may also affect the male reproductive tract, as male genital abnormalities have been reported in various animal species following prenatal, neonatal or postpubertal exposure to the non-steroidal oestrogen diethylstilbestrol (Newbold and McLachlan, 1985). Genistein reduces testicular and serum testosterone concentrations, pituitary gland luteinizing hormone (LH) content and the relative weight of prostatic lobes in adult mice (Strauss et al., 1998). However, some studies have shown in vitro that high levels of oestrogenic compounds may cross-react with the androgen receptor, as the oestrogen and androgen receptors are structurally similar steroid receptors (Maness et al., 1998). Thus, male and female hormones may each affect the expression of the other's receptors, with androgens affecting the expression of the estrogen receptor and vice versa (Poulin et al., 1989; Adesanya-Famuyiwa et al., 1999).

The aim of this study was to investigate the effects of soy isoflavone levels in the rodent diet on the Hershberger assay, and to determine whether these effects interfered with testosterone propionate, an androgenic reference compound and vinclozolin, an anti-androgenic compound (Hershberger et al., 1953; Ashby and Lefevre, 2000; Kelce et al., 1994). We modified the original Hershberger protocol by adding a week between castration and treatment initiation, to allow the rats to recover from surgery, as recommended by Ashby and Lefevre (2000). We began by assessing the effect of diet on accessory sex glands in the male rat using L5, a semisynthetic phytoestrogen free diet, DO4 (containing $8.5 \% \mathrm{w} / \mathrm{w}$ soybean meal and yeast) and DO3 $(22.5 \%$ $\mathrm{w} / \mathrm{w}$ of soybean meal and yeast).

\section{Materials and methods}

\subsection{Chemicals}

Testosterone propionate was purchased from Sigma (La Verpillière, France) and corn oil was obtained from Bouton d'Or (Dijon, France). Vinclozolin (98\% purity) was generously provided by the INRA Xenobiotic Metabolism Laboratory (Toulouse, France). Isoflurane $\left(\right.$ Forene $^{\circledR}$ ) was obtained from Abbott Rance (Rungis, France).

\subsection{Rodent diets}

Rodent semi-synthetic diet L5 was supplied by INRA (Jouy-en-Josas, France) and rodent diets DO4 and DO3, by UAR (Epinay sur Orge, France). The compositions of these diets are shown in Fig. 1.

\subsection{Genistein and daidzein content of the L5, DO4 and DO3 diets}

Isoflavones were extracted, in triplicate, from three samples of feed, each weighing $1 \mathrm{~g}$. Each sample was dissolved in $100 \mathrm{ml}$ of distilled water and $500 \mu \mathrm{l}$ of the resulting solution was removed during stirring for subsequent hydrolysis and extraction. The genistein and daidzein present in the $500 \mu$ l suspension of rodent feed in water were first hydrolysed with $\beta$-glucuronidase aryl sulphatase from Helix pomatia (Roche, Meylan, France). For this hydrolysis, we added $2 \mathrm{ml}$ of a $10 \mu \mathrm{l} /$ $\mathrm{ml}$ solution of $\beta$-glucuronidase aryl sulphatase in acetate buffer $(\mathrm{pH} 5 ; 0.01 \mathrm{M})$. The mixture was incubated for $48 \mathrm{~h}$ at $37{ }^{\circ} \mathrm{C}$, with gentle shaking. Hydrolysis was monitored using external standards run in parallel. These standards contained $1 \mathrm{mg} / \mathrm{ml}$ genistin or $1 \mathrm{mg} / \mathrm{ml}$ daidzin, the glycoside forms of genistein and daidzein, respectively. ELISA was used to check recovery for the hydrolysis of external standards. A liquid-liquid extraction was performed three times with $5 \mathrm{ml}$ of acidethyl acetate. Organic extracts were pooled and evaporated to dryness and the resulting powder was dissolved in $500 \mu$ of assay buffer (PBS-T-PS-DMSO-PBS containing $0.1 \%$ porcine serum, $0.05 \%$ Tween- 20 and $1 \%$ DMSO), with sonication to ensure that dissolution was complete. Sonication was performed with a VibraCell 75021 Ultrasonic Processor from Bioblock Scientific. Samples were treated for $2 \mathrm{~min}(3 \mathrm{~W})$. Three external extraction standards containing genistein and daidzein were run in parallel to check the rate of recovery for the extraction procedure. Extracts were stored at $-20{ }^{\circ} \mathrm{C}$ until assay.

Samples were analysed by specific ELISA, as described by Le Houérou et al. (2000). The results obtained are presented in Fig. 1.

\subsection{Animals and dietary treatments}

Pregnant female Wistar rats were purchased from Janvier (Le Genest-Saint-Isle, France). The rats were maintained under controlled temperature $\left(22{ }^{\circ} \mathrm{C}\right)$, humidity (40\%) and light (12:12) conditions in an specific pathogen-free animal house. Rats were fed with the tested diets and water ad libitum, daily food consumption being measured. At parturition, offspring were sexed and ten male rats were associated with one mother until they were 20 days old. At this age, the animals were weaned, weighed, and randomised by 

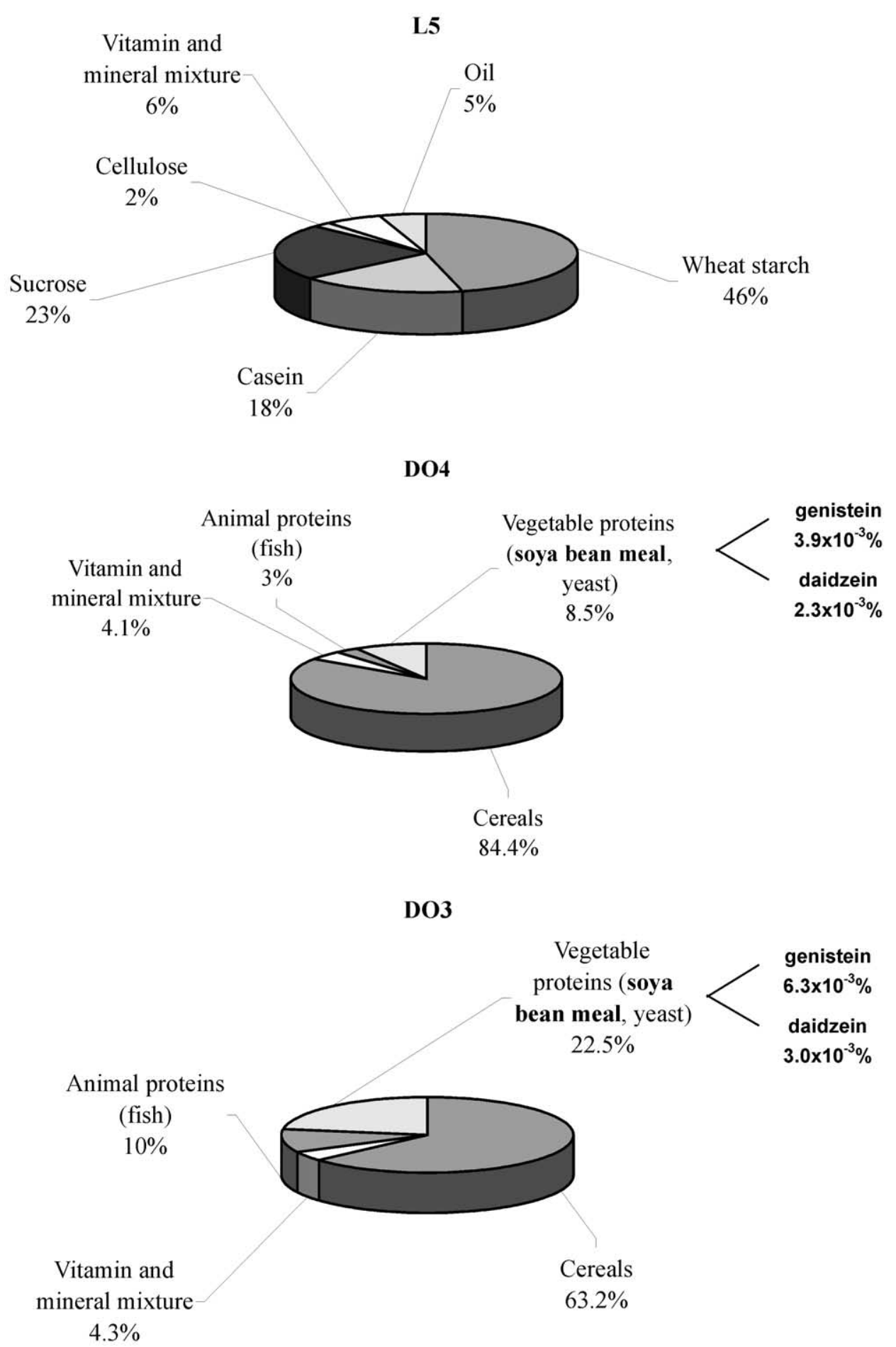

Fig.1. Formulae and soy isoflavone content of the three rodent diets used. Values were determined with triplicate samples.

weight into experimental groups (eight animals per group). At the age of 21 days, animals were castrated under isoflurane anaesthesia according to the Charles River protocol and allowed to recover for one week. Gavage (vinclozolin, 25, 50, $100 \mathrm{mg} / \mathrm{kg}$ b.w./day) and subcutaneous injections (testosterone propionate, 0.1, $0.2,0.4,0.8 \mathrm{mg} / \mathrm{kg}$ b.w./day) were performed once daily for 10 days. Vinclozolin and testosterone propionate were dissolved in corn oil and used to treat animals at doses of $5 \mathrm{ml} / \mathrm{kg}$ body weight and $2.5 \mathrm{ml} / \mathrm{kg}$ body weight, respectively. Control groups received only the vehicle (corn oil). We carried out three series of experiments (Fig. 2). In the first, animals were fed L5 for 28 days (exposure via maternal milk and then from diet), and then castrated male rats were fed the various diets (L5, DO4 and DO3) for ten days, during the Hershberger 
a

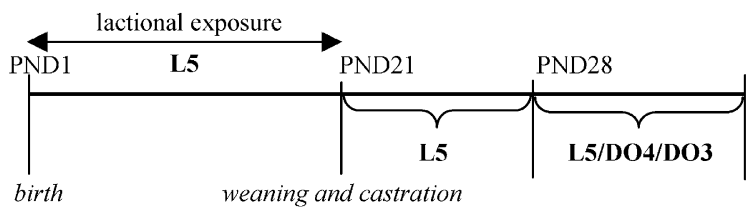

b

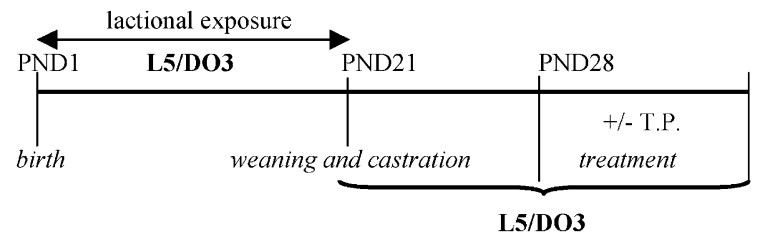

C

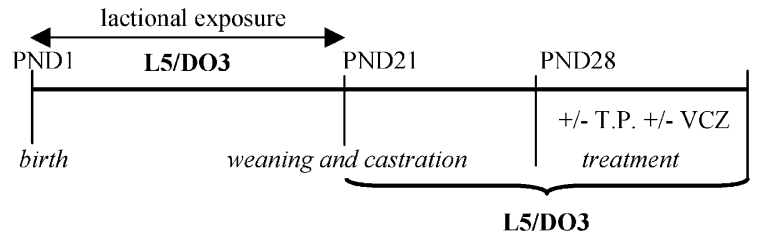

Fig. 2. Schematic representation of the experimental protocols. (a) 28day-old castrated rats were fed the L5, DO4 or DO3 diet. (b) Rats were fed throughout their lifetime with the L5 or DO3 diet. After castration, they were treated for ten days, from 28 to 38 days of age, with testosterone propionate injected subcutaneously $(0.1,0.2,0.4$, or $0.8 \mathrm{mg} / \mathrm{kg}$ b.w./day). (c) Rats were fed throughout their lifetime with L5 or DO3 diet. After castration they were treated for ten days (PND 28-38) with testosterone propionate $(0.4 \mathrm{mg} / \mathrm{kg} \mathrm{b.w./day)}$ injected subcutaneously. They were also gavaged during this period with vinclozolin $(25,50$ or $100 \mathrm{mg} / \mathrm{kg}$ b.w./day).

treatment period. In the second and third experiments, animals were fed L5 or DO3 throughout their lifetime. Twenty-four hours after the last treatment, animals were weighed and killed. Seminal vesicles, prostate and the bulbo cavernosus/levator ani (BC/LA) muscle were removed and immediately weighed.

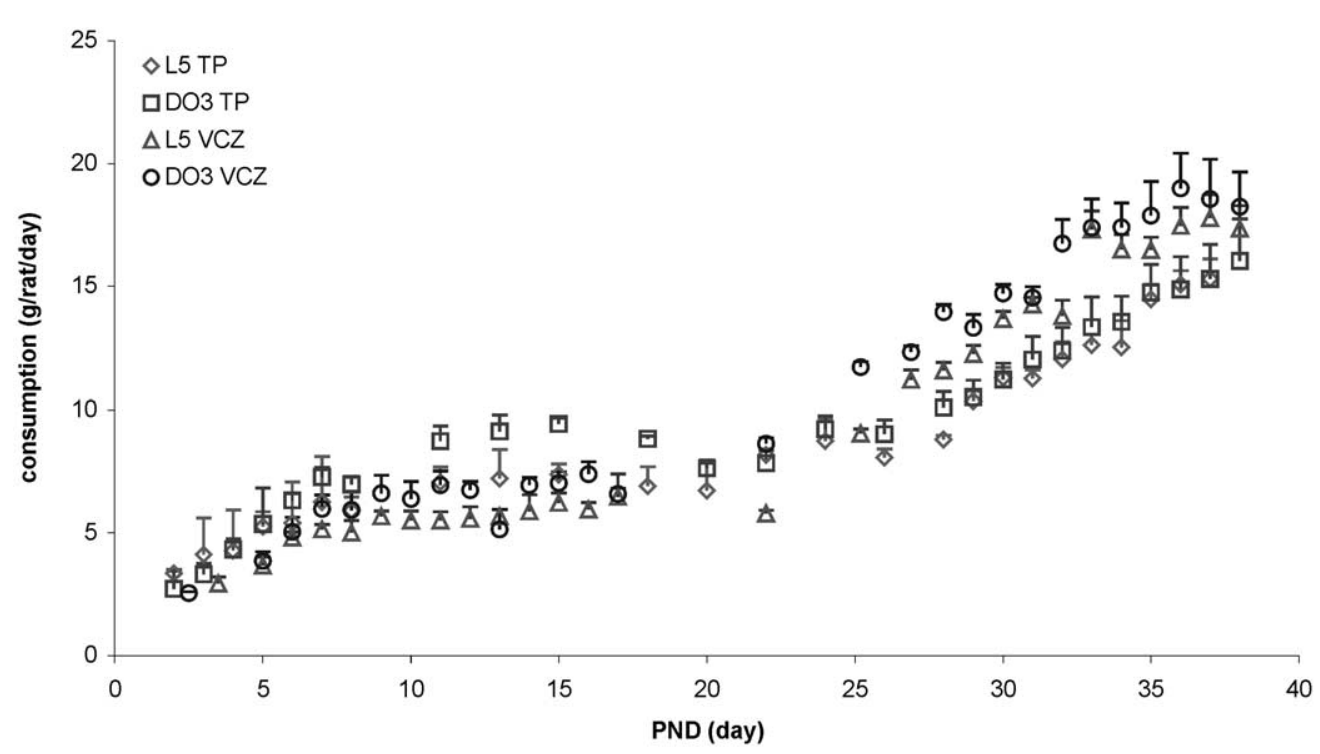

Fig. 3. Changes in food consumption (g/animal/day) in rats fed the L5 ( $\diamond$ and $\triangle$ ) and DO3 $(\square$ and $\bigcirc)$ diets throughout their lifetime. Values are expressed as means \pm S.D.

\subsection{Statistical analysis}

Body weight and food consumption are expressed as means \pm S.D. (standard deviation) and the various groups were compared using Student's $t$-test $(P<0.05$ considered significant). The data for all organs are expressed as means \pm SEM (standard error of the mean). They were analysed by ANOVA, followed by Fisher's protected least significant difference test (Fisher's PLSD). Values of $P<0.05$ were considered significant.

\section{Results}

\subsection{Change in body weight}

In the first experiment (10 days of exposure), we in rats fed DO4 and DO3 than in rats fed L5. In the other experiments, diet had no effect on the increase in body weight of the male Wistar rats (Fig. 3, Table 1). In the life-long exposure experiments, diet did not influence food consumption. Treatments had no effect on body weight, with the exception of the highest dose of testosterone propionate in rats fed DO3.

\subsection{Effect of dietary phytoestrogens on accessory sex organ weights in castrated rats}

After feeding on a particular diet for 10 days (Fig. 2a) or life-long exposure (Fig. $2 \mathrm{~b}$ and c), no significant effect of dietary phytoestrogens was observed on the relative weights of the seminal vesicles, prostate and BC/LA (Fig. 4 and controls of Figs. 5 and 6). observed a significantly smaller increase in body weight 
Table 1

Body weight gain $(\mathrm{g})$ of rats during the last ten days (treatment period) in various Hershberger experiments

\begin{tabular}{|c|c|c|c|c|}
\hline \multirow[t]{2}{*}{ Experiment } & \multirow[t]{2}{*}{ Treatment } & \multicolumn{3}{|l|}{ Rodent diet } \\
\hline & & L5 & DO4 & DO3 \\
\hline 1 & Control & $49.8 \pm 4.12$ & $38.8 \pm 3.73 * * * a$ & $42.6 \pm 2.87^{* * a}$ \\
\hline 2 & Control & $72.1 \pm 8.93$ & & $77.3 \pm 3.43$ \\
\hline 2 & TP $0.1 \mathrm{mg} / \mathrm{kg}$ b.w./day & $72.4 \pm 6.66$ & & $75.1 \pm 5.63$ \\
\hline 2 & TP $0.2 \mathrm{mg} / \mathrm{kg}$ b.w./day & $70.9 \pm 9.81$ & & $76.9 \pm 7.72$ \\
\hline 2 & TP 0.4 mg/kg b.w./day & $73.3 \pm 6.52$ & & $78.2 \pm 4.80$ \\
\hline 2 & TP $0.8 \mathrm{mg} / \mathrm{kg}$ b.w./day & $77.6 \pm 6.03$ & & $85.4 \pm 3.40^{9,{ }^{* * *}, \mathrm{~b}^{*}}$ \\
\hline 3 & Control & $80.1 \pm 8.43$ & & $75.9 \pm 6.61$ \\
\hline 3 & TP 0.4 mg/kg b.w./day & $89.4 \pm 7.22 * b$ & & $83.1 \pm 8.29$ \\
\hline 3 & $\mathrm{TP}+\mathrm{VCZ} 25 \mathrm{mg} / \mathrm{kg}$ b.w./day & $82.3 \pm 9.59$ & & $81.5 \pm 4.80$ \\
\hline 3 & $\mathrm{TP}+\mathrm{VCZ} 50 \mathrm{mg} / \mathrm{kg}$ b.w./day & $81.4 \pm 7.17$ & & $80.1 \pm 5.25$ \\
\hline 3 & $\mathrm{TP}+\mathrm{VCZ} 100 \mathrm{mg} / \mathrm{kg}$ b.w./day & $84.4 \pm 9.17$ & & $77.2 \pm 7.89$ \\
\hline
\end{tabular}

1: Ten-day diet exposure; 2 and 3: Life-long exposure. Values are expressed as means \pm S.D. $(n=8)$.

Asterisks indicate significant differences in one-way ANOVA followed by Student's $t$-test (*: $P<0.05 ; * *: P<0.01 ; * * *: P<0.001)$.

${ }^{\text {a }}$ Data were compared for the various diets.

b Data were compared with respective controls.

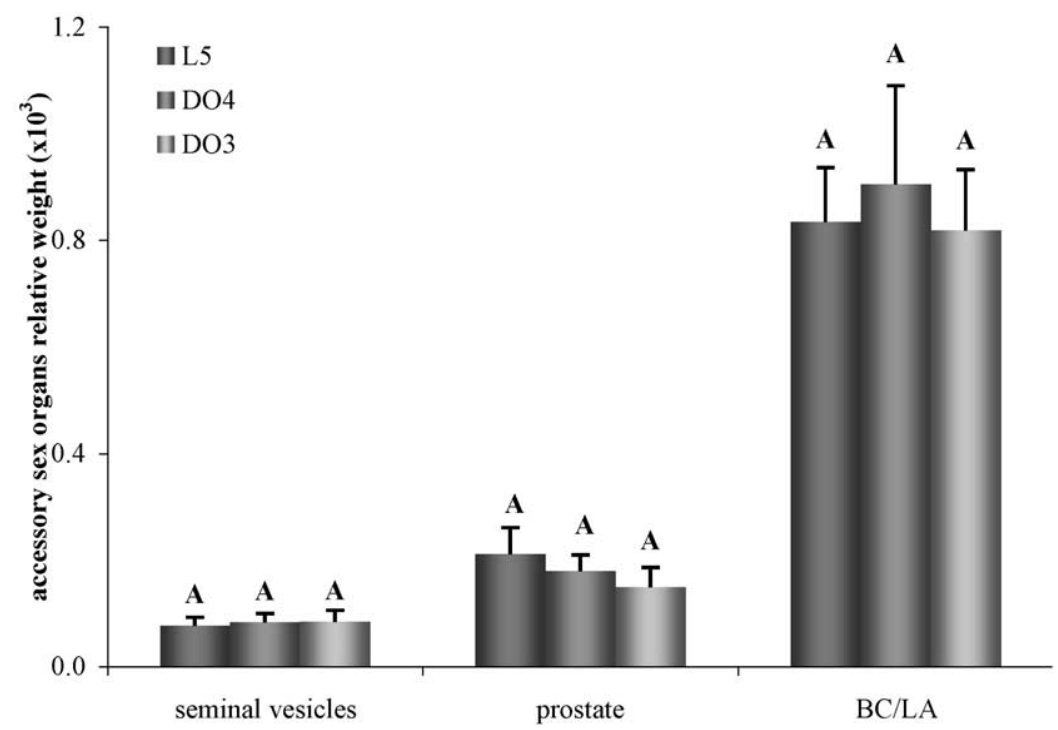

Fig. 4. Effect of the three diets on the relative weights of the seminal vesicles, the prostate and the BC/LA muscle. Results are presented as means \pm S.E.M. $(n=8)$. Different letters indicate significantly different values $(P<0.05)$.

\subsection{Effect of dietary phytoestrogens on the androgenic activity of testosterone propionate}

The administration of testosterone propionate to rats resulted in a significant, dose-dependent increase in the relative weight of the seminal vesicles, for concentrations of at least $0.2 \mathrm{mg} / \mathrm{kg}$ b.w./day (Fig. 5A). Similar increases were observed in the relative weights of the $\mathrm{BC} / \mathrm{LA}$ and prostate, at concentrations of at least 0.1 $\mathrm{mg}$ testosterone propionate $/ \mathrm{kg}$ body weight (Fig. 5B and $\mathrm{C}$ ). At concentrations of testosterone propionate exceeding $0.4 \mathrm{mg} / \mathrm{kg} \mathrm{b.w./day,} \mathrm{the} \mathrm{relative} \mathrm{weights} \mathrm{of} \mathrm{the}$ prostate and $\mathrm{BC} / \mathrm{LA}$, expressed as percentage of controls, reached a plateau. The effects on seminal vesicle and prostate weights were significantly milder in rats fed DO3 than in rats fed the L5 diet (Fig. 5A and B). Seminal vesicles appeared to be the most sensitive organ, and BC/LA the least sensitive. A dose of $0.4 \mathrm{mg} /$ $\mathrm{kg}$ b.w./day was used in subsequent experiments (antiandrogenic studies).

\subsection{Effect of dietary phytoestrogens on the anti-andro- genic activity of vinclozolin}

An anti-androgenic response was observed following the administration of vinclozolin to rats at doses of 25 $\mathrm{mg} / \mathrm{kg}$ b.w./day and over (Fig. 6). This response was clearly dose-dependent, as shown by the weights of the 

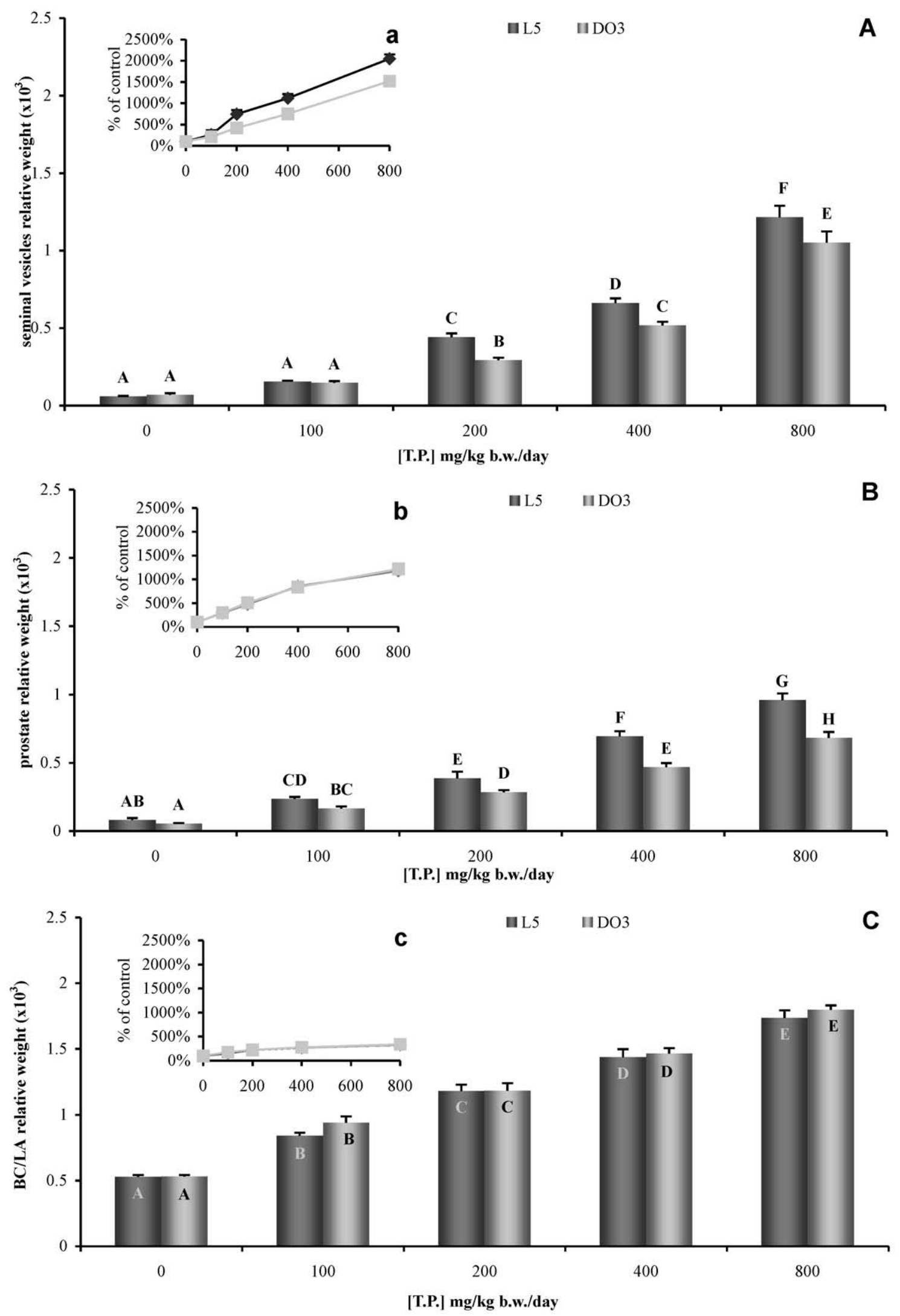

Fig. 5. Effect of testosterone propionate on the relative weights of the seminal vesicles (a, A), the prostate (b, B) and the BC/LA muscle (c, C) in rats fed on L5 or DO3. Results are presented as percentages with respect to the corresponding controls (a, b, c) and as absolute relative weights (A, B, C), as means \pm S.E.M. $(n=8)$. Different letters indicate significantly different values $(P<0.05)$. 

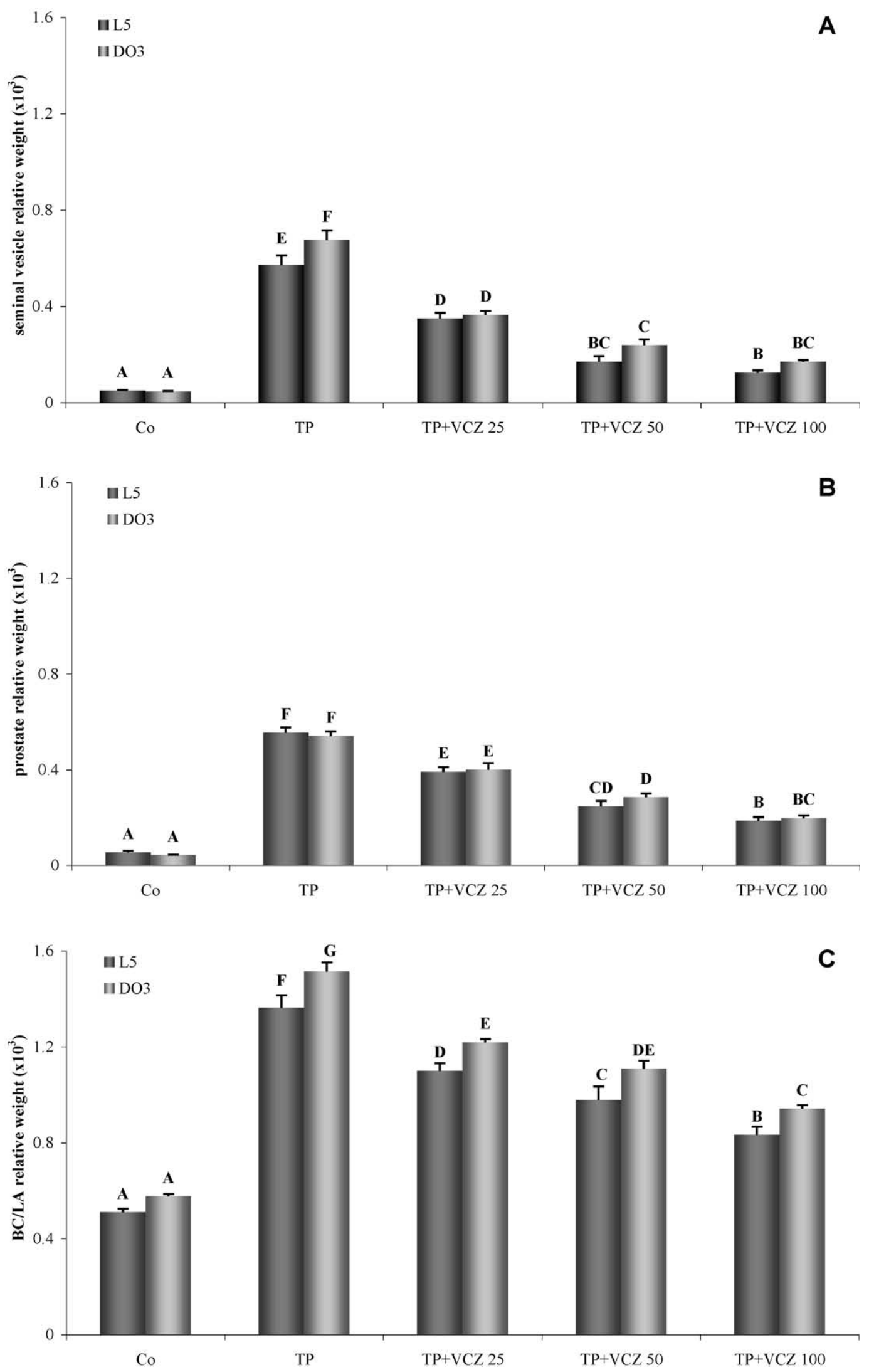

Fig. 6. Effect of vinclozolin on the relative weights of the seminal vesicles (A), the prostate (B) and the BC/LA muscle (C) in rats fed on L5 or DO3. Results are presented as means \pm S.E.M. $(n=8)$. Different letters indicate significantly different values $(P<0.05)$. 
prostate and $\mathrm{BC} / \mathrm{LA}$. Seminal vesicle weight was significantly lower following treatment with 25,50 and 100 $\mathrm{mg} / \mathrm{kg} \mathrm{b.w./day,} \mathrm{and} \mathrm{the} \mathrm{response} \mathrm{to} \mathrm{treatment} \mathrm{was} \mathrm{sig-}$ nificant and dose-dependent for doses of $25-50 \mathrm{mg} / \mathrm{kg}$ b.w./day. A marked effect was observed with the seminal vesicles and prostate, with the BC/LA again the least sensitive organ (weight of BC/LA lower by a factor of 2.7 , whereas seminal vesicle weight was lower by a factor of 11 and prostate weight, by a factor of 10). Phytoestrogen content did not influence the anti-androgenic effect of vinclozolin although, for the $\mathrm{BC} / \mathrm{LA}$, the slight difference observed between diets at all doses was significant.

\section{Discussion}

In this study, we investigated the possible effect of phytoestrogens, such as soy isoflavones present in the diet, on the Hershberger assay, by measuring the relative weights of the seminal vesicles, prostate and $\mathrm{BC} / \mathrm{LA}$.

Soybean contains a high proportion of genistein and daidzein, two compounds with well-known oestrogenic activity in vivo and in vitro (Welshons et al., 1990; Whitten and Naftolin, 1998). After ten days, or even after 38 days of being fed a particular diet, we observed no androgenic effect of the soybean meal in the diet on the weights of the accessory sex glands. We then performed a series of experiments with only the DO3 diet, which contains the highest proportion of daidzein and genistein. We found that the seminal vesicles and prostate, used as indicators of androgenic and/or anti-androgenic activity in vivo, presented similar response profiles, with the seminal vesicles being the most sensitive organs. In contrast, the BC/LA appeared to be the least sensitive organ in Wistar rats. Ashby and Lefevre (2000) showed that the prostate and Cowper's gland were the most sensitive organs in Hershberger assays performed on Alderley Park rats. Prostate development depends on the bioconversion of testosterone to dihydrotestosterone; seminal vesicles are less sensitive to this bioconversion (EDSTAC, 1998) but their development is dependent on both testosterone and dihydrotestosterone. Some authors have suggested that the seminal vesicles are sensitive organs but there is a wide range of intrinsic variation (Ashby and Lefevre, 2000). In this study, we observed no wide intrinsic variation in response with seminal vesicles.

We observed a significant difference between the Wistar rats fed DO3 and those fed L5, in terms of the androgenic response of the seminal vesicles and prostate. The DO3 diet did not modify the BC/LA response, probably due to the lack of sensitivity of this accessory sex organ. Furthermore, genistein and daidzein have been shown to inhibit $5 \alpha$-reductase type 2 , which has a high affinity for testosterone, in vitro (Hiipakka et al., 2002). Our data are consistent with previous reports that $\mathrm{BC} / \mathrm{LA}$ growth is testosterone-dependent and sug- gesting that $5 \alpha$-reductase inhibitors should not affect these muscles (Blohm et al., 1986). Thus, the use of a combination of three parameters, such as the relative weights of seminal vesicles, prostate and $\mathrm{BC} / \mathrm{LA}$, can be useful for studies of the mechanisms underlying endocrine disruption.

In contrast, in the presence of the anti-androgen vinclozolin, we observed no effect of diet on accessory sex organs such as seminal vesicles and prostate. However, the effect of diet on the BC/LA muscles was very weak. These data could be due to relative weight differences between controls, even though such differences were not significant, suggesting that the treatment was not entirely responsible for the results. Indeed, if the results were expressed as percentages with respect to the control, then no difference between diets was observed.

The isoflavone genistein acts as an oestrogen agonist in the prostate of adult rodents (Santti et al., 1998). Genistein and daidzein may also exert their endocrine disrupting effects via indirect mechanisms, such as decreasing androgen receptor expression (Fritz et al., 2002). Careful attention should be given to the selection and use of the most appropriate diet, according to the objectives to be attained, in endocrine disrupter studies.

Further studies are required to increase our understanding of the biological role played by phytoestrogens in the androgenic response observed in the Hershberger assay. The effect of diet on the response to testosterone propionate, which is probably associated with the soy isoflavone content of the diet, may be due to direct or indirect mechanisms, such as the absorption, metabolism and/or degradation of testosterone propionate in rats. It would be of great interest to analyse further the expression and binding of oestrogen and androgen receptors in the accessory sex glands of the rat, such as the prostate and seminal vesicles, as we used castrated animals whereas Fritz et al. (2002) used intact animals.

$\mathrm{BC} / \mathrm{LA}$ muscles appear not to be very sensitive in the Hershberger assay. Nevertheless, it is important to consider this organ as it responds only to testosterone. In the testosterone propionate experiment, the observed effect of diet may also be due to an indirect mechanism such as $5 \alpha$-reductase inhibition, which leads to a decrease in DHT levels.

In conclusion, rodent diets containing phytoestrogens, such as daidzein and genistein, may alter the results of studies of androgen activity. A standardised open-formula diet devoid of phytoestrogens, such as L5, should therefore be recommended if the Hershberger assay is to be performed.

\section{Acknowledgements}

We would like to thank L. Decocq for excellent technical assistance. 


\section{References}

Adesanya-Famuyiwa, O.O., Zhou, J., Wu, G., Bondy, C., 1999. Localization and sex steroid regulation of androgen receptor gene expression in rhesus monkey uterus. Obstet. Gynecol. 93, 265-270.

Ashby, J., Lefevre, P.A., 2000. Preliminary evaluation of the major protocol variables for the Hershberger castrated male rat assay for the detection of androgens, antiandrogens, and metabolic modulators. Regulatory Toxicology and Pharmacology 31, 92-105.

Bickoff, E.M.A., Livingston, A.L., Hendrickson, A.P., Booth, A.N., 1962. Relative potencies of several estrogen-like compounds found in forages. J. Agric. Food Chem. 10, 410-412.

Blohm, T.R., Laughlin, M.E., Benson, H.D., Johnston, J.O., Wright, C.L., Schatzman, G.L., Weintraub, P.M., 1986. Pharmacological induction of $5 \alpha$-reductase deficiency in the rat: separation of testosterone-mediated and $5 \alpha$-dihydrotestosterone-mediated effects. Endocrinology 119, 959-966.

Boettger-Tong, H., Murthy, L., Chiappetta, C., Kirkland, J.L., Goodwin, B., Adlercreutz, H., Stancel, G.M., Mäkelä, S., 1998. A case of a laboratory animal feed with high estrogenic activity and its impact on in vivo responses to exogenously administered estrogens. Environmental Health Perspectives 106, 369-373.

EDSTAC (1998). Endocrine Disruptor Screening and Testing Advisory Committee (EDSTAC) Final Report, August 1998. US Environmental Protection Agency. Internet access: http://www.epa.gov/ scipoly/oscpendo/history/finalrpt.htm. In Chapter five: screening and testing: Endocrine Disruptor Screening and Testing Advisory Committee, pp. 1-27.

Fritz, W.A., Wang, J., Eltoum, I.-E., Lamartiniere, C.A., 2002. Dietary genistein down-regulates androgen and estrogen receptor expression in the rat prostate. Molecular and Cellular Endocrinology $186,89-99$.

Hershberger, L.G., Shipley, E.G., Meyer, R.K., 1953. Myotrophic activity of 19-nortestosterone and other steroids determined by modified levator ani muscle method. P.S.E.B.M. 83, 175-180.

Hiipakka, R.A., Zhang, H.-Z., Dai, W., Dai, Q., Liao, S., 2002. Structure-activity relationships for inhibition of human $5 \alpha$-reductases by polyphenols. Biochemical Pharmacology 63, 1165-1176.

Kelce, W.R., Monosson, E., Gamcsik, M.P., Laws, S.C., Gray, L.E.J., 1994. Environmental hormone disruptors: evidence that vinclozolin develomental toxicity is mediated by antiandrogenic metabolites. Toxicology and Applied Pharmacology 126, 276-285.

Kurzer, M.S., Xu, X., 1997. Dietary phytoestrogens. Annu. Rev. Nutr. 17, 353-381.

Le Houérou, C., Bennetau-Pelissero, C., Lamothe, V., Le Menn, F., Babin, P., Bennetau, B., 2000. Syntheses of novel hapten-protein conjugates for production of highly specific antibodies to formononetin, daidzein and genistein. Tetrahedron 56, 295-301.

Maness, S.C., McDonnell, D.P., Gaido, K.W., 1998. Inhibition of androgen receptor-dependent transcriptional activity by DDT isomers and methoxychlor in HepG2 human hepatoma cells. Toxicology and Applied Pharmacology 151, 135-142.

Mazur, W., 1998. Phytoestrogen content in foods. Baillieres Clinical Endocrinology and Metabolism 12, 729-742.

Newbold, R.R., McLachlan, J.A., 1985. Diethylstilbestrol associated defects in murine genital tract development. In: McLachlan, J.A. (Ed.), Estrogens in the Environment. Elsevier Science, Amsterdam.

Odum, J., Tinwell, H., Jones, K., Van Miller, J.P., Joiner, R.L., Tobin, G., Kawasaki, H., Deghenghi, R., Ashby, J., 2001. Effect of rodent diets on the sexual development of the rat. Toxicological Sciences 61, 115-127.

Poulin, R., Simard, J., Labrie, C., Petitclerc, L., Dumont, M., Lagacé, L., Labrie, F., 1989. Down-regulation of estrogen receptors by androgens in the ZR-75-1 human breast cancer cell line. Endocrinology 125, 392-399.

Reinli, K., Block, G., 1996. Phytoestrogen content of foods. A compendium of literature values. Nutrition and Cancer 26, 123 148.

Santti, R., Mäkelä, S., Strauss, L., Korkman, J., Kostian, M.L., 1998. Phytoestrogens: potential endocrine disruptors in males. Toxicology and Industrial Health 14, 223-237.

Strauss, L., Mäkelä, S., Joshi, S., Huhtaniemi, I., Santti, R., 1998. Genistein exerts estrogen-like effects in male mouse reproductive tract. Molecular and Cellular Endocrinology 144, 83-93.

Thigpen, J.E., Setchell, K.D., Ahlmark, K.B., Locklear, J., Spahr, T., Caviness, G.F., Goelz, M.F., Haseman, J.K., Newbold, R.R., Forsythe, D.B., 1999. Phytoestrogen content of purified, open- and closed-formula laboratory animal diets. Laboratory Animal Science $49,530-536$.

Verdeal, K., Ryan, D.S., 1979. Naturally occurring estrogens in plant foodstuffs. Journal of Food Protection 42, 577-583.

Welshons, W.V., Rottinghaus, G.E., Nonneman, D.J., Dolan-Timpe, M., Ross, P.F., 1990. A sensitive bioassay for detection of dietary estrogens in animal feeds. J. Vet. Diagn. Invest. 2, 268-273.

Whitten, P.L., Naftolin, F., 1998. Reproductive actions of phytoestrogens. Bailleres Clinical Endocrinology and Metabolism 12, 667690.

Yamasaki, K., Takeyoshi, M., Yakabe, Y., Sawaki, M., Imatanaka, N., Takatsuki, M., 2002. Comparison of reporter gene assay and immature rat uterotrophic assay of twenty-three chemicals. Toxicology 170, 21-30. 